\title{
EPISTOLAR
}

\section{ULTIMA CARTA DE GOETHE A GUILLERMO DE HUMBOLDT}

Después de unalarga pausa involuntaria empiezo de la manera siguiente y sin embargo improvisando. A los animales les enseñan sus órganos dijeron los antiguos; yo añado: también a los hombres, pero tienen la ventaja de enseñar a su vez a sus órganos.

Para cualquier actividad, y por ende, para culquier talento hay que postular algo innato, que actúe por si mismo y que lleve consigo.inconscientemente las disposiciones necesarias, obrando de manera tan consecuente que, aunque encierre una regla, pueda en última instancia desenvolverse sin meta y fin.

Cuanto antes el hombre se dé cuenta de que hay una profesión, de que hay un parte que le ayuden a un aumento regulado de sus disposiciones naturales tanto más feliz será.

Todo lo que pueda recibir de afuera no le hace daño a su individualidad inherente. El mejor genio es aquel que todo lo recibe en sí, quien sabe asimilarse todo, sin que en lo más mínimo mengüe a su verdadero destino fundamental lo que se llama el carácter, sino que lo estimule y que lo capacite por entero en la medida de lo posible. 
Aqui entran las relaciones múltiples entre lo consciente y lo inconsciente; imagínese un talento musical que quiera arquitecturar una partitura seria: consciencia e inconsciencia vendrán a ser lo que es la trama a la urdimbre, parábola de la cual yo me sirvo con tanto gusto.

Los órganos del hombre, gracias al ejercicio, al aprendizaje, a la reflexión, al éxito, al fracaso, al favorecimiento, $y$ a la resistencia y siempre de nuevo gracias a la reflexión, unen inconscientementemente $y$ en libre actividad, lo adquirido con lo innato, de manera que se produzca una unidad que pone el mundo en asombro.

Estas generalidades deben servir para una rápida contestación de la pregunta y para la explicación de la hojita que retorna a Usted.

Hace más de sesenta años que la concepción del Fausto, de antemano clara en mi juventud, no descubría aún todo su orden.

Siempre me dejé acompañar suavemẹte por la intención, y solamente he trabajado en aquellas partes que me eran las más interesantes por aquel entonces, de modo que en la segunda parte quedaron lagunas que habrá que unir con el resto por un permanente interés.

En esto intervino indudablemente la gran dificultad de alcanzar a través de propósito y carácter lo que en sí mismo hubiese pertenecido sólo a la naturaleza libremente activa. Pero no sería bueno si después de una larga vida de activa reflexión no lo hubiera logrado, y no me amedrento por temor alguno de que se pueda distinguir lo más viejo de lo más nuevo, lo posterior de lo anterior, lo cual dejo a lectores futuros para su afectivo entendimiento.

Sin duda me causaría infinita alegría poder dedicar y comunicar en vida estas muy serias bromas a mis muy agradecidamente reconocidos y esti- 
mados amigos profusamente repartidos y poder escuchar su contestación. Pero el día es realmente tan absurdo y confuso que me convenzo que mis honrados y asiduos empeños por esta rara construcción serian mal retribuidos y se encallarian como el casco de una nave expuesta en las dunas y amenazando con ser sepultada por la arena de las próximas horas.

Dotrina desorientadora para acciones desorientadas gobierna el mundo y no tengo empeño más urgente que aumentar posiblemente lo que está en mi y lo que ha quedado y de cohibir mis particularidades, como usted mi digno amigo también lo efectúa en su burgo.

Comuníqueme por ende algo de sus trabajos; Riemer, como usted sabe muy bien, está fijado en iguales o semejantes estudios, y nuestros coloquios nocturnos conducen a menudo a los límites de su disciplina.

Perdón por esta hoja tardia! A pesar de mi aislamiento raras veces se halla una hora en la cual uno se quiera representar estos secretos de la vida.

\title{
Fielmente
}

\author{
J.W. v. GOETHE \\ (versión de Erwin Walter Palm).
}

